\title{
Population Growth and Environmental Changes: Conclusions Drawn from the Contradictory Experiences of Developing Countries
}

\author{
Barana Babiso Badesso'; Senbetie Toma Lachore ${ }^{2}$ and Aklilu bajigo Madalcho
}

\begin{abstract}
${ }^{1 \& 2}$ Department of Geography \& Environmental Studies, Wolaita Sodo University, Ethiopia; Email:babieamado@wsu.edu.et, senbetietoma@wsu.edu.et respectively ${ }^{3}$ Department of Natural Resource Management, Wolaita Sodo University, Ethiopia (Email: bajigoaklilu05@gmail.com) (PO Box: 138 Wolaita Sodo
\end{abstract}

\begin{abstract}
This review paper is intended to exhibit the interplays between environmental change and rapid population growth in developing countries. In the course of discussion, the impacts of rapidly population growing on the environment have been discussed, and evidence, from various parts of the world have been traced. Studies on the impacts of population pressure on environment have been critically reviewed. It is revealed that all across the developing countries, farm size is shrinking as farmers continue to subdivide holdings among their children. In countries such as Malawi, Rwanda, Ethiopia, Haiti, Nepal and Bangladesh, population growth rates are high, and the non-farm sector is still in its early stages of development. Demographic pressure, land scarcity, and land fragmentation drive greater rural vulnerability and poverty, marked by decreased food security, inadequate response to such natural disasters such as drought or pest infestations, weakened resilience to shocks, and poor health. It is not just the supply of food, fodder, and fuel wood but the resource base itself and the lives that depend upon it are being affected. The evidences pinpoints that man through his non-sustainable production and consumption patterns, is placed at the heart of environmental changes. However, contradictory view, and practices are also in place that the population growth has positive impacts environmental restoration and improvements, while other evidences show insignificant effect of population on the environment. This contradicting scenario puts scholars in argument, and still need further research. Hence, it would be a blind generalization to draw conclusion from this relationship alone, rather, another factor that acts beyond population pressure must also be considered to justify the impact of population on environmental changes.
\end{abstract}

Keywords: Climate change, Developing countries, Environmental change, Forest, Population growth

\section{Introduction}

There is an increasing recognition of the linkages between rapid population increase and the quality of the environment. Population growth and the resultant human activities generate pressures to the natural and man-made environments. This statement is demonstrated by the rapid decline in tropical forests, global warming, and world pollution, to mention only a few (UN, 1992). While the populations have reached the 6 billion mark in 1999, the world natural resource base has continued to be at a diminishing state. Today, similar consequences are evident at regional and national levels. 
Over the past century, many scholars maintained thinking that rapid population growth is the major cause of many environmental concerns especially in developing countries. Human beings have been viewed as destructive intruders to natural environment; hence, the solution is to effect stringent rules and legislation that protect the environment. Discussions of the interplay between population, economic development, and the environment predate the emergence of economics as a field of study. The recurrent theme was the balance between population and natural resources conceptualized as means of subsistence or, more concretely, food and water (UNFPA, 1991). The world population grew four-fold (from 1.6 billion to 6.1 billion) between 1900 and 2000 . This was coupled with a twenty to forty-fold increase in world GDP, leading to vastly higher living standards for a significant portion (but not all) of humanity. What is more notable than the unevenness of benefits accrued from the GDP growth is, however, the unsustainable utilization of the Earth's physical resources and the attendant environmental impacts.

As the $21^{\text {st }}$ century begins, growing numbers of people (86 million new people per year) and astronomical increases in consumption per capita, even in the formerly less developed countries (LDC) like China and India, are further depleting natural resources and degrading the natural environment. In many countries widespread water shortages, deterioration of arable land, unsustainable use of the natural habitats, and rampant pollution are undermining socio-economic progress and posing severe dangers for public health. There is no question that improving standards of living for the current poor of the world, plus providing for the billions still to come, will increase global demand for food, water, energy, wood, housing, sanitation, and disposal of wastes. Despite an emerging trend of a slowdown in population growth rates too many millions are still added each year there by increasing the pressure on available agricultural, fresh water, and other finite resources. "A new Germany is added annually, a new Los Angeles monthly". [http://www.fpif.org/briefs/vol4/v4n14pop.html]

The linkage between environment and population trends is a less documented phenomenon. Whereas the environment is considered to be the primary supply of resources for human use, population size and its composition generates the demand for these resources and the impact on the environment (UN, 1993). A large body of research traces changes in the ecosystem with respect to demographic growth through transformations of social, cultural and institutional factors. Those transformations could have positive or destructive effects on the environment 
depending on institutional realities market conditions, property rights, land distribution, taxes and subsidies on various types of production and consumption (FAO, 1983). According to several studies, the major problems now a day can be categorized in to environmental and social aspects. Environmental degradation has been manifested in deforestation, high erosion, water logging and flood-storms; which in turn has caused persistent food insecurity and absolute poverty. This review paper traces some of the reasons for, the ascent and then silencing of population growth as a key factor in discussions of environmental degradation. Therefore, this review was made (a) to overview the population and environment links where perhaps population pressure plays an important role by magnifying environmental degradation; (b) to exhibit the approaches adopted to address the problem of population pressure on environment.

\section{Theoretical Perspectives}

Plato and Aristotle were alert to the necessity of population's being self-sufficient in food, and warned the fact that cultivated land could not be expanded rapidly enough to match rapid population growth that would lead to overpopulation and poverty (UNFPA, 1991). Although early and medieval Christian doctrines generally considered population issues from a moral and ethical standpoint, some writers regarded the excessive growth of the known world population as the cause of poverty and suffering and attributed to nature the ability to re-establish the balance between population and resources through pestilence, famine and war. One should mention that not all theorists saw population growth in a negative light. In particular, mercantilist ideas in Europe during the seventeenth and eighteenth century reflected the positive aspects of large and growing populations and favoured policies to encourage marriage and large families.

For the last two centuries, the Malthusian perspective has shaped to a large extent the debate on population-development relationships. Both its advocates and foes shared concerns about the balance among demographic trends (essentially population growth), natural resources and economic growth and poverty. Yet, framing the population-environment relationships in terms of per capita availability of resources has led to opposing perspectives. On the one hand, the "limits to growth" perspective considers population growth fundamentally detrimental to the global system (Brown et al, 1999; Meadows and Randers, 1992) on the other hand, there is the view that population growth is a positive impetus for technological progress (Boserup, 1990; Simon, 1996). 
The Economic Commission for Africa (ECA) designed a population environment-developmentagriculture (PEDA) model which links population change, environment, socio-economic development and agriculture, to demonstrate the impact of different policy options on food security in the ECA region. The theoretical inspiration for PEDA comes from the "vicious circle model" that was originally developed by Partha Das Gupta (Cambridge University) and others. The vicious circle assumes a causal chain of interactions between poverty, high population growth, environmental degradation and decreasing per capita agricultural production that can trap certain rural societies into a vicious circle of increasingly destructive responses.

Over the course of human history, population growth and redistribution through migration have been the major anthropogenic forces altering the face of the earth (Wolman and Fournier, 1987). This has led to various theories and explanations of the linkages between demographic factors and changes in environment, including those of Malthus (1798), and others (Geist and Lambin, 2001; Barana et al., 2016). The theory of multiphasic response attempts to integrate into a comprehensive framework response to increasing population pressure (Bilsborrow, 1987; Bilsborrow and Geores, 1994).

There is growing concern that much of developing countries natural resource base and ecological environment are deteriorating mainly due to high loss of vegetative cover as a result of deforestation and conversion of savanna to cropland (UNECA, 1993). In developing countries, land degradation is one of the greatest threats which strike at the basic resource of the population. The degradation process is so acute in Africa that millions of people have fallen into poverty and have suffered famine and death. Overall, the effect of population pressure and resulting environmental degradation has driven the countries into widespread food insecurity, drought and famine for the decades. The main factors that are responsible for environmental degradation in developing countries such as Ethiopia include the removal of vegetation cover through deforestation and overexploitation of forest resources, in appropriate land cultivation, and agricultural land expansion, overgrazing, and other as ultimate causes. Elias, (2002) has stated that inappropriate land use and subsequent agricultural productivity decline while increased human population is putting pressure on the natural resources for the demand of basic necessity. This is considered as the major driving factors of deforestation for millennia in Ethiopia. The rapidly growing human and domestic animal population created the need for 
expanding crop cultivation and grazing land, and fuel wood demand (Teketay, 2001); it had a negative impact, and in turn exacerbated rapid land degradation.

\section{Approaches used in this review}

This review was made by evaluated literatures which focus on population and environmental issues. The available studies that point out the impact of population pressure on environmental change were critically reviewed. Throughout this process, literatures such as books, reports and articles were used. Through keyword searches in library catalogues, journal databases as well as the social sciences citation index were used to search materials recorded from years 1980 to 2016 GC. By using a narrative review approach, literatures review was conducted, and informal discussion with persons in the theme was made to draw conclusions on the arguments on population growth and environmental change.

\section{Population Growth vs. Environmental change}

\subsection{Deforestation and overexploitation of vegetation}

Land clearing in a shifting cultivation is largely driven by population growth, through the growth in requirements of food and other agricultural products. Comparatively, forest clearing for pastures is a minor factor on a global scale (although it is important in certain countries). The other cause of destruction of vegetation cover is its overuse by households, mainly from fuel wood collection. To cover vital energy needs, some households in developing countries resort to "free" gathered biomass fuels, including crop residues and animal dung but, most of fuel wood. When the annual use of wood exceeds the sustainable yield of wooded areas, forests and woodlands are gradually destroyed. This in turn triggers or accelerates soil erosion. Around 1980, FAO estimated that about 2 billion people (or $3 / 4$ of the population of developing countries at that time) depended on biomass for their daily energy consumption (FAO, 1983). But close to 1.4 billion of these could not meet their requirements without compromising future fuel wood supplies, and it was expected that the number would increase to 3 billion ( 2.4 billion in rural areas) be the year 2000. Overall, population pressure is determinant in vegetation loss, especially in areas with limited land reserves and energy sources. In the high population density areas of West Africa, for instance, concentrations of demand for arable land and-fuel wood lie at the root 
of resource abuse. It is in these areas that patches of desertification are the most visible due to deforestation and mismanagement of natural resources (Gorse and Steeds, 1987).

\subsection{Overgrazing}

Excessive livestock population pressure on the vegetation cover can be a crucial problem, especially in developing countries where rangelands usually are much more crowded than in the developed world (FAO, 1983). Accordingly livestock does not necessarily cause environmental problems; however, overgrazing can be a major factor in land degradation. For instance, it has caused,-half of the damage assessed in Africa and one- fourth in other developing regions. Cases such as the damage caused by goats in the Mediterranean area and elsewhere are well known as to (FAO, 1983). In Africa, the increase in cattle numbers and the decline in the quality of rangelands have been significant during the recent decades (FAO, 1986b). These two trends are obviously incompatible in the long run, and local crises are likely in the future. In Sudan for instance, the growth of the pastoralist population and increased livestock density have led to the extension of grazing activity into forests and semi-arid marginal lands, causing degradation in both zones (Bilsborrow and DeLargy, 1991). The recent study in Ethiopia by Barana (2016) shown that the grass lands are over-stocked and deteriorated beyond the carrying capacity and it became the major cause for severe environmental deterioration in the studied watershed.

Studies carried out in the Southern Ethiopian Highlands, showed high stocking rates with concentration of animals of up to 23 TLU per ha while under normal and well managed pastures the stocking rates is recommended to be 2-5 TLU per ha. This means that there are far more animal units on the land than it can support in the Southern Ethiopia, although an area represents one of the severely eroded land in Ethiopia (Barana, 2016).

As reported by Talbot (1989) in Kenya, population growth among both the Maasai pastoralists and the sedentary agricultural population have led to competition for land between the two groups, overgrazing and agricultural land in certain areas. The sedentarization of nomads, leading to the concentration of populations and herds on restricted ranges, has similar effects (Fratkin, 1981; Little, 1987). So do political conflicts that contribute to population and livestock concentration, which in turn perpetuate ecological degradation and food shortages" (Hjort af Orn's and Salih, 1991). As stated by Breulmann et al. (2007) land degradation usually arises 
from the demands of increasing populations that settle on the land in order to cultivate crops and graze livestock. However, the impact is manifested on loss of biodiversity, and loss of productive capacity, so that therefore transition from grassland dominated by perennial grasses to land dominated by non-palatable, toxic, thorny or halophyte shrubs is takes place. In the Sub-Saharan Africa, human population is increasing rapidly, forcing farmers to use grazing areas for arable farming. As a result, the smallholder farmers in in this part of Africa have integrated their livestock into their cropping systems and used crop residues as a main livestock feed resources (Ibrahim, 1999). The carrying capacity and quality of the grazing land is continuously declining in Ethiopia (Alemayehu, 2003).

\subsection{Improper agricultural management}

Population growth requires the extension of interference into new areas, and the subjection of these areas to the high levels of damage. It requires the occupation of sites of lower resilience and higher sensitivity for which existing management practices may be inadequate (Blaikie and Brookfield, 1987). Degradation then sets in, unless particular measures are taken to protect soil structure and maintain fertility. But such measures usually are absent; since this kind of practices takes place in situations where low-cost solutions are sought because of resource limitation to invest in land protection. Examples of populations driven upland by the saturation of lowland resources, with ensuing degradation and at times ecological collapse, are numerous: Ethiopia, Haiti, Nepal and the Philippines being perhaps the best known. Population pressures play an obvious role in most of these situations, but it must also be noted that unequal land distribution can worsen those pressures notably.

The chief problem with shifting cultivation today is that increasing populations and the need for higher production to feed them are pressuring many farmers to shorten or even eliminate the fallow. As a consequence, yields are lower and soil damage greater (FAO, 1983). Lele and Stone (1989) have described that due to rapid population growth in Senegal and Tanzania, environmental damage has observed after deforestation and subsequent decline in soil fertility: Pingali and Binswanger (1988) also reported evidence from Africa, that farmer-generated technical change is capable of sustaining slow-growing populations, but not rapid growth in both rural and urban population food demand. This is because high population pressure creates stresses within existing systems. 


\section{Population Growth vs. Climate Change}

Despite environmentalists' reluctance to be identified with the population issue, scientific studies of climate change are beginning to include the role of population growth again. Climate models describe the consequences of continued emissions of greenhouse gases both in terms of the expected parts per million ( $\mathrm{ppm}$ ) in the atmosphere and the associated temperature increase. The Intergovernmental Panel on Climate Change (IPCC), the principal scientific body assessing climate change scenarios, described the effects of climate change in its 2007 Fourth Assessment report. The IPCC, 2007 report stated that climate change is "unequivocal" and will likely cause climbing land and ocean temperatures, leading to rising sea levels, melting glaciers, receding ice and snow packs, intensifying heat waves and droughts, more frequent tropical storm activity and floods. In addition, it states the spread of insect-borne disease, changes in human and animal habitats, and irreversible species extinction. Climate disruption is also predicted to reduce the agricultural yields, impair the viability of natural resources, and undermine the habitability of many regions. O'Neill reported that slowing population growth could provide $16-29 \%$ of the emissions reductions, and suggested to be necessary by 2050 to avoid dangerous climate change. His study in 35 countries suggested that, slowed population growth could save 1.4 to 2.5 billion tons of carbon emissions per year by 2050, certainly help to solve the climatic problem (O'Neill, 2010).

The developing world, especially LDCs, already have adopted measures to slow population growth. Their policy statements suggest an awareness that population stabilization would help them adapt better to climate change. It is indicated in the World Health Organization evaluation reports from 40 National Adaptation Programmes of Action (NAPA) in developing countries that the goal of NAPAs is to identify and articulate their priorities for climate change adaption (Bryant et al., 2009). About $93 \%$ of the NAPAs identified the impact of rapid population growth on their ability to adapt climate change in at least one of the following ways: faster degradation of natural resources; increased demand for scarce resources; and heightened human vulnerability to extreme weather events (Bryant et al., 2009). Six of the countries listed curbing rapid population growth as their first climate change adaptation priority. Now it can be concluded that the risks associated with climate change suggest that limiting its causes, including population growth as a top priority. 


\section{Population Growth and Technological Factors on Land Degradation}

In many rural settings particularly but not only in Africa population has grown rapidly during the past 20 years or so, while technology and consumption levels have stagnated (or worse) and land degradation has accelerated. This could suggest that when population growth is rapid it becomes the decisive factor for the final outcome. Yet, when "technology" in turn undergoes a rapid adaptation process, its changes can offset the effects of total consumption growth (whatever the respective roles of population and per capita consumption growth in the latter). Java for instance, "despite the serious erosion that takes place in headwater areas and on land of high environmental sensitivity that is unsuited to irrigated terracing, exemplifies the high productivity obtainable under intensive management with extremely high densities of population" (Blaikie and Brookfield, 1987). Mortimore (1993) pointed out that the Close-Settled Zone of Kano (Nigeria) exhibited a stable agricultural system in a dry land area, despite the high population density. Study by Hyden et al., (1993) in Kenya, Nigeria, Rwanda, Tanzania and Uganda, also reported that in certain places "farmers have managed their lands, even under severe pressures, in a manner that has permitted sustained use to date". The report concluded that high population densities could be accommodated in many parts of East Africa. Tiffen et al. (1994) described a remarkable "success story" observed in the Machakos District of Kenya. They saw the case as confirming "the autonomous effects of an increased population, deriving from the availability of more mouths (more demand), more hands (more labour), and more brains (more people interacting more), accompanied by a reduction in the per capita costs of physical and social infrastructure". What conclusions can we draw from the variety of contradictory experiences?

There is no evidence that the same (or greater) improvements of environmental and economic outcomes could not have been made under slower population growth; there is no evidence either that the improvements are due to population growth rather than any other factor. In fact, the benefits listed by Tiffen et al., (1993) arise not from population growth, but from a sufficient population density. And there is of course no guarantee that comparable improvements will occur for other populations growing at the same rate. It would be easy to point to situations (in Ethiopia and other parts of Africa, the Philippines, Haiti and Nepal) where population growth conditions of the same kind as those observed in Machakos were associated with stagnation or even ecological collapse. Naturally, such cases do not prove, either, that "rapid population 
growth leads inexorably to environmental degradation", the proposal which Tiffen et al., (1994) purport to disprove, but that few, if any, actually propound. Policy-wise, it is critically important to address the ambiguity in Boserup's hypothesis regarding the innovation process itself. Blaikie and Brookfield (1987) ask: what is it that makes population pressure result in degradation rather than innovation? They point to a variety of explanations, including "the lack of access to productive resources on the part of the cultivator", and revolving around the various kinds of pressures which lead farmers to extract more from the land than it can sustainably give.

\section{Population growth and environmental concerns: Key Lessons}

Malthus had long hypothesized that populations growing exponentially would take over food production growing linearly. On the other hand, Boserup (1981) hypothesized that increasing population pressure will lead to adjustments in production and hence the quality and productivity of the land improves. This has been true because agricultural production managed to outpace population growth due to green revolution, which allowed for a much increased productivity. Hence, growth in agricultural production exceeded population growth for almost three decades (Squire, 2000). At present, there is enough food produced around the world, the problem is that the food is unevenly distributed. However, others argue that there are ecological limits to food production which may provide little scope for future expansion (Ehrlich and Holdren, 1971).

Contrary to this, case studies have highlighted situations where population growth and agricultural intensification have been accompanied by improved rather than deteriorating soil and water resources (Tiffen et al., 1994). Experiences from the study in Machakos, Kenya proved opposite to what has been discussed in the preceding paragraphs. Similar trends may also be witnessed in the highlands of Ethiopia, even though what is commonly known about rural Ethiopia. However, despite of continuity of backward farming practices, farmers in some parts of Wello have innovated and responded well to physical and social environment (Crummey and Winter-Nelson, 2003). In addition, in the enset based farming systems, especially in Wolaita, Kembata, Sidama and others, the number of trees and vegetative cover in general, has been increasing or at least has been maintained, despite these areas being few of the highly populated in the country. In the semi-arid and with relatively highly populated and marginal lands of Konso, still productive and support the population due to the indigenous knowledge of the people on soil conservation effects. To the other end, some of the northern highlands are 
degraded almost beyond recovery, despite the long history of government efforts to arrest soil erosion. This is because these areas were settled early and support high population, in addition to the nature of their topography and geology, which make them prone to this phenomenon.

From the preceding information, it is not possible to make a blanket conclusion as to whether population is likely to enhance land degradation, as in the case of the northern highlands or land will be rehabilitated, as in the case of the enset based farming systems in Ethiopia and Machakos in Kenya. Hence, socio-economic and biophysical aspects of each area should be considered in order to make relevant conclusions, which may lead to appropriate recommendations.

A recent studies in Ethiopia offered an intriguing solution to the environmental puzzle; a solution that is, nevertheless, difficult to implement. It promised that restoration of ecosystems to a much healthier form in the hills and slopes of the Ethiopian highlands is possible if these areas can be kept free of human and animal intervention (Stein et al., 2005). Some practical examples have also been offered. A recent study of a community in the southern regions showed that "in the mid-1980s, the average household kept 7-8 heads of cattle, but this has since declined to 1-2 head per household, because of shortages of feed, the conversion of grazing areas to farmland, the forced sale of livestock to pay off taxes and debts, and losses from disease" (Tilahun et al., 2001).

Therefore, it seems population has been viewed as an intermediate variable: technical, economic or social variables (e.g. poverty, defective markets, polluting technologies, distortionary policies, etc.) would work "through" population growth, which merely "exacerbates" the effects of these processes. Population affects environment through: Increasing pressure on marginal lands, overexploitation of soils, overgrazing, and forest clearing for wood, soil erosion, silting, flooding, increased use of pesticides, fertilizer, water for irrigation, increased salinization, pollution of fisheries, migration, shortage of water supply and sanitation, industrial waste dangers, indoor air pollution, and mud slides (Alain Marcoux, 1999). 


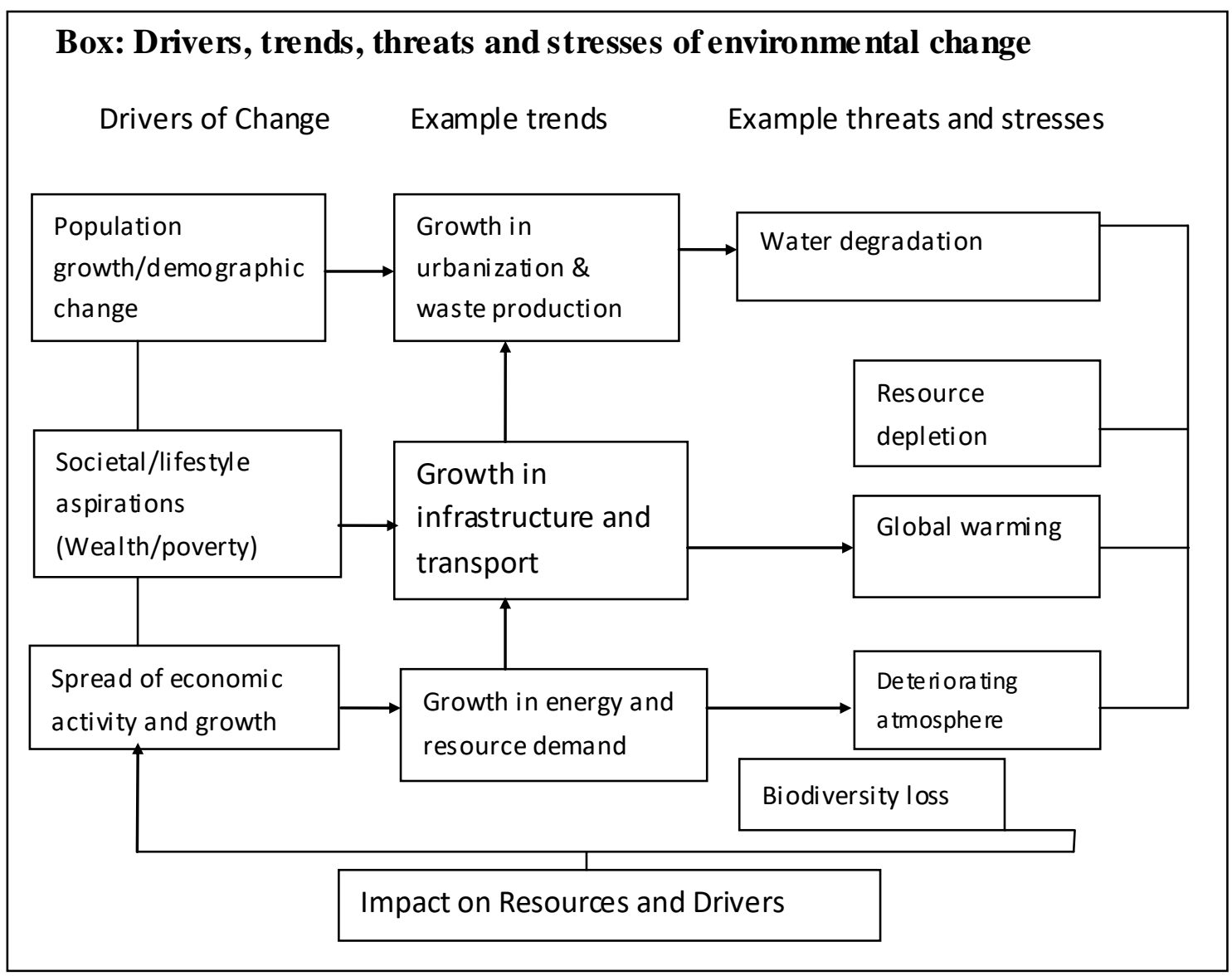

Source: Developed from Foresight (2000).

\section{Social and institutional factors on Environmental Change}

\subsection{Agrarian structures and land degradation}

Land degradation on a holding depends in part on how intensively the land is exploited, and in part on the holder's ability and willingness to undertake conservation measures. These two factors in turn are influenced by farm size although not in an entirely linear manner. A "natural" factor in the fragmentation of land into small holdings is population growth. All across the developing world, farm size is shrinking as farmers continue to subdivide holdings among their children. In countries such as Malawi, Rwanda, Haiti, and Bangladesh, population growth rates are high, and the non-farm sector is still in its early stages of development. Farms now average less than 0.5 hectares in some areas. Ever-increasing numbers have become nearly or entirely landless (Clay et al., 1994). Another factor, of course, is social inequality within the population leading to skewed structures of land ownership. Pressures towards land degradation are stronger 
in this case, because land quality and vulnerability are usually not equally shared either: "Inequities in land ownership may also encourage soil erosion. In Andean Latin America, for example, wealthy ranchers often use the relatively level valley floors to graze cattle, forcing the small, poor landowners onto the steep slopes to produce subsistence crops" (FAO, 1983). Population pressure in turn contributes to unequal practices, because a deteriorating population/resources situation leading to decreasing average well-being contributes to trigger or accelerate land concentration: With more people, the increased demand for food results in increased competition for arable land, tending to change land prices (Bilsborrow and DeLargy, 1991). Overall, poverty is usually seen as adding considerably to resource overuse in developing countries. Poor households are often virtually forced to overuse natural resources for daily subsistence. Rural households in fuel wood- deficit countries strip foliage and burn crop and animal residues for fuel rather than using them for fertilizer and this contributes to desertification.

\subsection{The religious Dogma: Christianity and Population in developing countries}

Christian doctrine gives three reasons to oppose population stabilization. The Old Testament commands population increase; choosing who lives usurps God's role; and some church authorities forbid modern contraceptives and, most importantly, abortion. Christian opposition to stopping population growth derives from God's command in Genesis to Adam and Eve: "Be fruitful and increase in number; fill the earth and subdue it" Genesis 1:28 (New International Version) or "Be fruitful, and multiply, and replenish the earth, and subdue it," Genesis 1:28 (King James Version) depending on the translation.

The second religious concern about population stabilization arises from the fear of "playing God" by choosing who will and will not exist. To conservative Christians, using contraceptives to limit reproduction undermines God's authority more than choosing when to have intercourse, because contraception prevents reproduction. The Christian community's multiple factions complicate its stance on modern contraceptives, abortion, and population stabilization. "Mainstream" Christians as individuals and as a church tend to support contraceptives and abortion. The Anglican Church accepted the use of contraceptives by married couples in 1930. In 1994, the General Convention of the Episcopal Church affirmed its pro-choice stance (The Episcopal Church, Indianapolis, 1994 report). By contrast, Evangelical Protestants oppose both 
contraceptives and abortions. The Catholic Church explicitly forbids modern contraceptives and abortion, according to the teachings of Pope Paul VI and subsequent popes (http://rcrc.org/about/members.cfm). It is unlikely that environmental activists would alienate substantial conservative Christian support by supporting curbs on population growth. Conservative Christians are already lukewarm about or outright opponents of mitigating climate change, tending instead to deny the existence of anthropogenic climate change, believe that God will provide, or be generally pro-business and anti-liberal.

\section{Conclusions and arguments}

This in depth review has been conducted to see the interplays between population growths and environmental changes over the past half century, focusing on the developing countries. Population growth is a contributing factor to many types of environmental stresses. The role of increasing population size is especially prominent as the major force driving the basic needs of natural resource bases including food production. This creates environmental stresses on water, forests, soil and air that stem from agriculture. However, as concluded in the 1990s by an indepth scientific inquiry, population growth "is not the only factor affecting the rate of resource degradation and in many contexts it is undoubtedly not the most important factor. There is a huge array of obstacles to expanded food production and better resource management. These include weak land tenure systems, inadequate credit availability, biased agricultural prices and exchange rates, adverse tax policies, weak agricultural extension services, excessive government control, and civil wars. But few if any of these problems will be resolved through rapid population growth. They are the context on which this growth will be imposed as stated in (Preston, 1994).

Nevertheless, some of the reviewed findings indicate, a population growth had a positive indirect effects (i.e., people seem to have responded over time by introducing technological improvements like terracing, drainage channels, mixed cropping, and so on. In this development path, there are only minor visible negative effects of population growth so far like environmental degradation (Holden and Sankhayan, 1998), however reality is still more complex. The reviewers generally agree with that of Ehrlich's idea that population was the dominant factor in 
environmental damage because other factors would work "through" population growth, which merely "exacerbates" the effects of these processes.

In conclusion, final caveat about environmental degradation itself is a less well-understood concept than presently thought and by itself a critical research area. In addition, it is suggested that environmental change is inevitable, and under the continued influence of economic activity and population growth, hence, it is likely to increase in the decades ahead. In this context, the change may be desirable if it is possible to absorb increasing populations and satisfy growing material needs without compromising sustainability issue. It is increasingly argued that forest conversion is not wholly harmful and on balance often may benefit society, especially the rural poor (Lomborg, 2001; Wunder, 2001). In addition, this review paper also argues that the existing Christian view that population growth and environmental degradation are inextricably linked, and are self-enforcing is based on the limited empirical findings.

In general, pressure on the environment may result from rapid population growth, distribution and migration, especially in ecologically vulnerable ecosystems. The increasing rate of exploitation of the natural resources is probably a function of an increase in the number of people due to increased demand for food, water and arable land; and due to environmental degradation, the consequences are manifested on human welfare. On the other hand, many poor people are able to adopt protective mechanisms through collective action which reduce the impacts of population pressure on economic and environmental change; rather they make it as an opportunity to reverse the environmental changes. Therefore, this paper then suggests that it is equally important to focus on the root causes of environmental change other than population that aggravates the changes to worst level.

\section{Acknowledgements}

We are grateful to all authors referred, as they provided access to most of the data used and to proofreaders for most helpful comments. As usual, we are solely responsible for the contents.

\section{References}

Alain M. (1999). Potential population-supporting capacity of lands: environmental aspects. Population, Environment and Development, New York, United Nations, 1994, pp. 256-261. 
Alemayehu Mengistu and Sissay Amare, 2003. Integrated Livestock Development Project (ILDP). Livestock Feed Resources Survey. North Gondar, Ethiopia. 75 pp.

Barana B. (2016). Socioeconomic Driving Forces of Land use/Cover Dynamics and its Implications in Wallecha Watershed, Southern Ethiopia. GJHSS (B): Vol XVI Issue VI Version I, pp 49-58

Barana B., Senbetie T., Aklilu B. (2016). Land use/Land Cover Dynamics and its Implication on Sustainable Land Management in Wallecha Watershed, Southern Ethiopia. Global Journal of Science Frontier Research (H) Volume XVI, Issue IV, 49-63.

Bilsborrow, R. (1987). Population pressures \& agricultural development in developing countries: A conceptual framework \& recent evidence. World Development, 15(2):183-203.

Bilsborrow, R. and P. DeLargy (1991): Population growth, natural resource use and migration in the third world: the cases of Guatemala and Sudan. In: Resources, environment and, pp. 125-147. New York: Population Council/Oxford University Press.

Bilsborrow, R. E., and M. Geores (1994). "Population Change and Agricultural Intensification in Developing Countries." In L. Arizpe, D. Major, and P. Stone, eds. Population and the Environment: Rethinking the Debate. New York: Westview Press, pp. 171-207.

Bilsborrow, R., and M. Geores (1992). Rural Population Dynamics and Agricultural Development: Issues and Consequences Observed in Latin America. Ithaca, NY: Cornell University, Population and Development Program, and International Institute for Food, Agriculture and Development.

Blaikie P. and H. Brookfield (1987): Land degradation and society. London, Methuen.

Boserup, E. (1976). Environment, population and technology in primitive societies. Population and Environment Review (New York), Vol. 2, No.1, pp 21-36.

Boserup, E. (1981). Population and technology, Oxford: Oxford University Press

Boserup, E., 1990, Economic and Demographic Relationships in Development: Essays Selected and Introduced by T. Paul Shultz, Baltimore, MD: The Johns Hopkins University Press.

Breulmann M., Böer B., Wernery U., Wernery R., El Shaer H., Alhadrami G., Gallacher D., Peacock J., Ali Chaudhary S., Brown G., Norton J., 2007. The Camel from tradition to modern times: A Proposal towards combating desertification via the establishment of camel farms based on fodder production from indigenous plants and halophytes. UNESCO DOHA, July 2007. P12. 
Brown, Gardner and Halwel (1999). Beyond Malthus: Nineteen Dimensions of the population challenge: Worldwatch Environmental Alert Series. New York.W.W.Norton \& Company.

Bryant, Leo, Louise Carver, Colin Butler, and Ababu Anage. (2009). “Climate change and family planning: least-developed countries define the agenda." Bulletin of the World Health Organization 87 (September 2009): 852-857.

Clay, D.C., M. Guizlo and S. Wallace (1994): Population and land degradation. EPAT/MUCIA Working Paper No 14. Madison: University of Wisconsin.

Dregne H. E. (1986). Desertification of arid lands. In: El-Baz, F., Hassam, M.H.A., (eds) Physics of Desertification, Martinus Nijhoff Publisher, Boston

Ehrlich, P., and J. Holdren (1971). The impact of population growth. Science (Washington, D. C.), vol. 171, pp. 1212-1217.

Elias, E. (2002). Farmers'Perceptions of Soil Fertility Change and Management.SOS Sahel \& institute for sustainable development. Doctoral Dissertation. Addis Ababa, Ethiopia. $252 \mathrm{p}$.

FAO (1983): Keeping the land alive. Soil erosion - its causes and cures (by H.W. Kelley), Soils Bulletin No 50. Rome.

FAO (1986b): Atlas of African Agriculture. Rome.

Foresight (2000): Making the Future Work for You. London: Department of Trade and Industry.

Fratkin, E. (1991): Surviving drought and development: Ariaal pastoralists of northern Kenya. Boulder: Westview Press.

Geist, H. J., and E. F. Lambin (2001). What drives tropical deforestation? A meta-analysis of proximate and underlying causes of deforestation based on sub-national case study evidence. Louvain-la-Neuve, Belgium: LUCC International Project Office: 116.

General Convention. 1995. Journal of the General Convention of The Episcopal Church, Indianapolis, 1994. New York: (http://www.episcopalarchives.org. Accessed Feb, 15, 2017.

Gorse, J.E. and D.R. Steeds (1987): Desertification in the Sahelian and Sudanian zones of West Africa. World Bank Technical Paper No 61. Washington.

Hart (1998). Doing a Literature Review: Releasing the Social Science Research Imagination: SAGE publications: London.

Hjort Orns A. and M. Salih (1991): Research and development issues for African dry lands, Ambio, Vol. XX, No. 8, pp. 388-394. 
Holden S.T. and P. L. Sankhayan, 'Population Pressure, Agricultural Change and Environmental Degradation in the Western Himalayan Region of India', Forum for Development Studies, 1998:2, pp. $271-300$.

Hyden, G., R. Kates and B. Turner (1993): Beyond intensification. In: Population growth and agricultural change in Africa (B. Turner, G. Hyden and R. Cates, eds.). Gainsville: University of Florida Press.

Ibrahim H.1999. Feed Resources for Ruminant Livestock. ILRI Slide Series 1. ILRI (International Livestock Research Institute), Nairobi Kenya 44 pp.

IPCC. (2007): Synthesis Report. Contribution of Working Groups I, II and II to the Fourth Assessment Report of the Intergovernmental Panel on Climate Change. Written by The Core Writing Team and edited by R.K. Pachauri and A. Reisinger. Geneva: IPCC, 2008. http://www.ipcc.ch/publications_and_data/ar4/syr/en/contents.html.

Lambin, E., S. Agbola, A. Angelsen, J. Bruce, O. Coomes, R. Dirzo, G. Fischer, C. Folke, P. George, K. Homewood, J. Imbernon, R. Leemans, X. Li, E. Moran, M. Mortimore, P. Ramakrishnan, J. Richards, H. Skånes, W. Steffen, G. Stone, U. Svedin, T. Veldkamp, C. Vogel, J. Xu, B. Turner and H. Geist (2001). "The causes of land-use and land-cover change: moving beyond the myths." Global Environmental Change 11(4): 261-269.

Lele, U. and S.W. Stone (1989): Population pressure, the environment and agricultural intensification: variations on the Boserup hypothesis. MADIA Discussion Paper No 4. Washington: The World Bank.

Little, P. and M. Horowitz, eds. (1987): Lands at risk in the third world: local-level perspectives. Boulder/London: Westview Press.

Lomborg, B. (2001) The Skeptical Environmentalist - Measuring the Real State of the World. Cambridge: Cambridge University Press.

Malthus, Thomas. An Essay on the Principle of Population: The First Edition (1798) with Introduction and Bibliography. The Pickering Masters. Edited by E.A. Wrigley and David Souden. London: W. Pickering, 1986.

Meadows D. \& J. Randers (1992): Beyond the Limits: Confronting Global Collapse; Envisioning a sustainable Future. Post Mills, Vermont: Chelsea Green Publishing Company. 
Mortimore, M. (1993): Northern Nigeria: land transformation under agricultural intensification. In: Population and land use in developing countries (C.L. Jolly and B.B. Torrey, eds.), pp. 42-69. Washington: National Research Council/National Academy Press.

O’Neill, Brian, Michael Dalton, Regina Fuchs, Leiwen Jiang, Shonali Pachauric, and Katarina Zigovad. (2010).“'Global demographic trends and future carbon emissions.” Proceedings of the 125 National Academies of Sciences. 11 October 2010.

Pingali, P. and H.P. Binswanger (1988): Population density and farming systems: the changing locus of innovations and technical change. In: Population, food and rural development (R.D. Lee et al., eds.), pp. 51-76. Oxford: Clarendon Press.

Pingali, P.L., Y. Bigot \& H. Binswanger (1987). Agricultural Mechanisation and the Evolution of Farming Systems in Sub-Saharan Africa.The World Bank, Washington, D.C.

Preston (1994). The Dissolution of Britain.

Repetto, R. (1987): Population, resources, environment: an uncertain future, Population Bulletin, Vol. 42, No. 2 (July).

Report of the International Conference on Population and Development, Cairo, 5-13 September 1994. United Nations A/CONF. 171/13: Report of the ICPD (94/10/18). http://www.un.org/popin/icpd/conference/offeng/poa.html. Accessed Feb, 16, 2017.

Simon, J. (1986): Theory of population and economic growth. Oxford: Blackwell.

Simon, J. (1996). The Ultimate Resource: Revised Edition. Princeton, NJ: Princeton University.

Stein H., Hans L., Bekele Sh., (2005). Economic Reforms and Soil Degradation in the Ethiopian Highlands: A Micro CGE Model with Transaction Costs, Department of Economics and Social Sciences, Agricultural University of Norway

Talbot, L. (1989): Demographic factors in the resource depletion and environmental degradation in East African rangelands. In: Population and resources in a changing world: current readings (K. Davis et al., eds.), pp. 315-323. Stanford: Morrison Institute for Population and Resource Studies.

Teketay, D. (2001). Deforestation, Wood Famine, and Environmental Degradation in Ethiopia's Highland Ecosystems: Urgent Need for Action. North east African studies. 8, pp 53-76.

Tiffen, M., Mortimore M. and Gichuki F., (1994): Population growth and environmental recovery: policy lessons from Kenya. Gatekeeper Series No 45. London: International Institute for Environment and Development. 
Tilahun Amede, et.al. ( Reversing the degradation of arable land in the Ethiopian Highlands. Managing Africa's Soils No. 23, Areka Research Centre, 2001

UN, (1992): Agenda 21. Program of action for sustainable development. New York.

UN, (1993): Population, Environment and Development in Tanzania, Demographic Training Unit (University of Dares Salaam) and United Nations Department of Economic and Social Development, New York (URT-89-PO7).

UNFPA (1991), Population, Resources and the Environment: The Critical Challenges, United Nations Fund for Population Activities, New York.

Wolman, M., and F. Fournier (1987). Land Transformation in Agriculture. John Wiley \& Sons.

Wunder, S. (2001) Poverty alleviation and tropical forests - what scope for synergies? World Development, 29 (11): 1817-1833. 